\title{
Empyema and bacteremic pneumococcal pneumonia in children under five years of age ${ }^{* * * *}$
}

\author{
Empiema e pneumonia pneumocócica bacterêmica \\ em menores de cinco anos de idade
}

\author{
Maria Regina Alves Cardoso, Cristiana Maria Costa Nascimento-Carvalho, \\ Fernando Ferrero, Eitan Naaman Berezin, Raul Ruvinsky, \\ Clemax Couto Sant'Anna, Maria Cristina de Cunto Brandileone, \\ Maria de Fátima Bazhuni Pombo March, Ruben Maggi, Jesus Feris-lglesias, \\ Yehuda Benguigui, Paulo Augusto Moreira Camargos; the CARIBE group
}

\begin{abstract}
We compared bacteremic pneumococcal pneumonia (BPP) and pneumococcal empyema (PE), in terms of clinical, radiological, and laboratory findings, in under-fives. A cross-sectional nested cohort study, involving under-fives (102 with PE and 128 with BPP), was conducted at 12 centers in Argentina, Brazil, and the Dominican Republic. Among those with PE, mean age was higher; disease duration was longer; and tachypnea, dyspnea, and high leukocyte counts were more common. Among those with BPP, fever and lethargy were more common. 1t seems that children with PE can be distinguished from those with BPP on the basis of clinical and laboratory findings. Because both conditions are associated with high rates of morbidity and mortality, prompt diagnosis is crucial.

Keywords: Empyema, pleural; Pneumonia, pneumococcal; Pneumococcal infections.
\end{abstract}

\section{Resumo}

Comparamos crianças menores de cinco anos com pneumonia pneumocócica bacterêmica (PPB) àquelas com empiema pneumocócico (EP) quanto aos achados clínicos, radiológicos e laboratoriais. Um estudo de coorte aninhado transversal, com 102 crianças com EP e 128 com PPB, foi realizado em 12 centros na Argentina, no Brasil e na República Dominicana. Nas crianças com EP, a média de idade e a duração da doença foram maiores. Taquipneia, dispneia e contagem de leucócitos alta foram mais comuns nas crianças com EP; febre e letargia foram mais comuns naquelas com PPB. Parece possivel distinguir crianças com EP de crianças com PPB a partir de achados clínicos e laboratoriais. Como essas duas doenças estão associadas a altas taxas de morbidade e mortalidade, o diagnóstico rápido é crucial.

Descritores: Empiema pleural; Pneumonia pneumocócica; Infecções pneumocócicas.

Streptococcus pneumoniae is widely recognized as the leading cause of community-acquired pneumonia (CAP)-related mortality during hospitalization, as well as being the most common cause of empyema in children. The incidence of complicated pneumococcal CAP (CP-CAP) has been reported to be increasing worldwide. ${ }^{(1)} \mathrm{ln}$ Scottish children in the 1-4 year age bracket, there was a tenfold increase in empyema admissions in the period between the 1980s and the year

*Study carried out at the University of São Paulo School of Public Health, São Paulo, Brazil; the Federal University of Bahia School of Medicine, Salvador, Brazil; the Pedro de Elizalde Children's Hospital, Buenos Aires, Argentina; the Santa Casa School of Medical Sciences in São Paulo, São Paulo, Brazil; the Durand Municipal Hospital, Buenos Aires, Argentina; the Martagão Gesteira Institute of Pediatrics and Child Care, Rio de Janeiro, Brazil; the Center for Meningitis, Pneumonia, and Pneumococcal Infections, Department of Bacteriology, Adolfo Lutz Institute, São Paulo, Brazil; the Pernambuco Mother and Child Institute, Recife, Brazil; the Dr. Robert Reid Cabral Children's Hospital, Santo Domingo, Dominican Republic; the Department of Child and Adolescent Health and Development, Pan American Health Organization, Washington, DC, USA; and the Department of Pediatric Pulmonology, Federal University of Minas Gerais Hospital das Clínicas, Belo Horizonte, Brazil.

Correspondence to: Paulo Camargos, Departamento de Pediatria, Faculdade de Medicina da Universidade Federal de Minas Gerais, Avenida Alfredo Balena, 190, Sala 267, CEP 30130-100, Belo Horizonte, MG, Brasil.

Tel. 5531 3409-9772. Fax: 5531 3409-9664.E-mail: paulo.camargos@pq.cnpq.br or pcamargs@medicina.ufmg.br

Financial support: This study received financial support from the Canadian International Development Agency (CIDA); the Pan American Health Organization; the World Health Organization Department of Child and Adolescent Health and Development; and the Boston University Applied Research on Child Health (ARCH) Project (United States Agency for International Development cooperative agreement no. HRN-A-00-960010-00).

Submitted: 16 July 2013. Accepted, after review: 28 October 2013.

**A versão completa em português deste artigo está disponível em www.jornaldepneumologia.com.br 
2005. ${ }^{(2)}$ This increase might be related to host susceptibility, individual characteristics, and pathogen virulence.

Few studies have investigated the characteristics of CP-CAP, especially those of CP-CAP associated with pleural empyema or bacteremia-although few cases of pneumococcal pneumonia are bacteremicin children under 5 years of age, who are at the highest risk of death from CAP. Bacteremic pneumococcal pneumonia (BPP) is considered an advanced stage of severe pneumococcal pneumonia, in which early recognition and appropriate management can have a favorable impact on the outcome. ${ }^{(3)}$ Given that pleural empyema and BPP are potentially severe, it is important to recognize their clinical peculiarities in order to provide early and appropriate management.

In a recent study of hospitalized CAP patients, the prevalence rates of pleural effusion and empyema were reported to be $27 \%$ and $17 \%$, respectively. ${ }^{(3)}$ In another study, empyema was found in $83(11 \%)$ of 767 children hospitalized with CAP; in comparison with the children with CAP without empyema, those with empyema were older, had longer symptomatic periods, and were more likely to receive nonsteroidal anti-inflammatory drugs. ${ }^{(4)}$ The objective of the present study was to compare children under 5 years of age with BPP and those with pneumococcal empyema (PE) in terms of their clinical, radiological, and laboratory features.

A cross-sectional nested cohort study was conducted at 12 centers in Argentina, Brazil, and the Dominican Republic and included 2,536 children 3-59 months of age hospitalized with severe CAP, the results having been published elsewhere. ${ }^{(5)}$ On admission, blood cultures and, when appropriate, pleural fluid cultures were performed. S. pneumoniae was isolated from 283 children by standard procedures used in local referral laboratories. Most (90\%) of the children lived in urban settings, and none had received the conjugate pneumococcal vaccine or steroidal/nonsteroidal anti-inflammatory drugs. Cases of BPP were defined as those in which S. pneumoniae was isolated from blood culture. Cases of PE were defined as those in which S. pneumoniae was isolated from pleural fluid culture.

The exclusion criteria were as follows: showing signs of very severe pneumonia (including severe malnutrition, stridor in a calm child, unconsciousness, convulsions, nasal flaring, and central cyanosis); and presenting with concurrent infections. Patients with concomitant PE and BPP $(n=3)$ and those with pleural effusion of unknown cause $(n=50)$ were also excluded.

A favorable response to the initial treatment (i.e., conventional doses of intravenous ampicillin or penicillin G for BPP and PE patients alike) was defined as unequivocal clinical improvement within the first $48 \mathrm{~h}$ after hospital admission; conversely, treatment failure was defined as no improvement (persistent fever-body temperature being measured at least every $6 \mathrm{~h}$-tachypnea, difficulty breathing, or hypoxemia) after at least $48 \mathrm{~h}$ of antibiotic therapy or deterioration during antimicrobial therapy. ${ }^{(5)}$ Demographic, clinical, radiological, and laboratory data were obtained on admission. In addition, the length of hospital stay and the treatment outcome were recorded. Descriptive statistics were calculated, and two multiple logistic regression models were used, both of which were controlled for age. One of the models included variables obtained on admission and the other included variables obtained during hospitalization.

The present study included 230 children under 5 years of age (102 children with PE and 128 children with BPP). There was no significant difference between the two groups in terms of antibiotic use prior to hospital admission ( $p=$ 0.23). Table 1 displays the frequency distribution and the comparison (multivariate analysis) of the two groups of children on admission and during hospitalization.

In brief, our logistic regression analysis showed that, on hospital admission, children with PE were older and presented with a longer symptomatic period before hospitalization. In addition, tachypnea, difficulty breathing, and a leukocyte count $>15,000$ cells $/ \mathrm{mm}^{3}$ were more common in those children. Persistent fever was one of the most common findings during the first days of hospitalization, requiring further investigation (chest X-ray, chest ultrasound, or both). Fever (axillary temperature $>37.5^{\circ} \mathrm{C}$ ) and lethargy at diagnosis/baseline tended to be more common in the children with BPP. The hospital stay tended to be longer for the children with PE ( $p<0.001$; data not shown).

In the children with $\mathrm{PE}$, the most common serotypes were 14, 1, 6B, 3, 9V, 19A, and 5, 
Table 1 - Comparison (multivariate analysis) of children with pneumococcal empyema and those with bacteremic pneumococcal pneumonia on admission and during hospitalization.

\begin{tabular}{|c|c|c|c|c|}
\hline Characteristic & $\begin{array}{c}\text { PE } \\
(n=102)\end{array}$ & $\begin{array}{c}\text { BPP } \\
(\mathrm{n}=128)\end{array}$ & $\begin{array}{c}\text { Adjusted OR } \\
(95 \% \mathrm{Cl})\end{array}$ & $\mathrm{p}$ \\
\hline \multicolumn{5}{|l|}{ On admission } \\
\hline Age (months) & $19(12-33)$ & $13(9-22)$ & $1.03(1.00-1.05)$ & 0.01 \\
\hline \multicolumn{5}{|l|}{ Duration of disease ${ }^{b}$} \\
\hline$\leq 3$ days & 17.7 & 34.4 & 1 & 0.013 \\
\hline 4-6 days & 39.2 & 35.1 & $2.84(1.23-6.58)$ & \\
\hline$\geq 7$ days & 43.1 & 30.5 & $3.12(1.35-7.20)$ & \\
\hline Tachypnea $^{\mathrm{b}, \mathrm{c}}$ & 91.2 & 75.6 & $4.16(1.54-11.22)$ & 0.005 \\
\hline Difficulty breathing ${ }^{b}$ & 87.9 & 70.9 & $3.61(1.51-8.63)$ & 0.004 \\
\hline Body temperature $>37.5^{\circ} \mathrm{C}$ on admission ${ }^{\mathrm{b}}$ & 42.4 & 68.2 & $0.32(0.17-0.63)$ & 0.001 \\
\hline Lethargy ${ }^{b}$ & 53.5 & 67.7 & $0.35(0.17-0.71)$ & 0.004 \\
\hline Leukocyte count $>15,000$ cells $/ \mathrm{mm}^{3 \mathrm{~b}}$ & 48.5 & 29.8 & $2.13(1.10-4.13)$ & 0.02 \\
\hline \multicolumn{5}{|l|}{ During hospitalization } \\
\hline Difficulty breathing on the $3 r d d^{b}{ }^{b}$ & 57.6 & 27.0 & $2.9(1.52-5.56)$ & 0.001 \\
\hline Body temperature $\left({ }^{\circ} \mathrm{C}\right)$ on the $3 \mathrm{rd} \mathrm{day}^{\mathrm{a}}$ & $37.6(37.0-38.8)$ & $37.0(36.6-38.0)$ & $1.65(1.05-2.59)$ & 0.028 \\
\hline Treatment failure $\mathrm{b}^{\mathrm{b}}$ & 17.6 & 12.5 & $0.39(0.14-1.07)$ & 0.06 \\
\hline Length of hospitalization ${ }^{\text {a }}$ & $11(7-15)$ & $7(5-10.5)$ & $1.09(1.02-1.17)$ & 0.004 \\
\hline
\end{tabular}

PE: pneumococcal empyema; and BPP: bacteremic pneumococcal pneumonia. ${ }^{\text {a }}$ alues expressed as median (interquartile

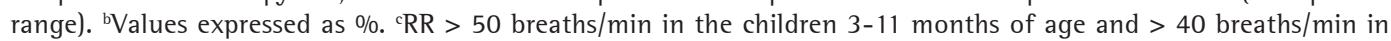
those $\geq 12$ months of age.

accounting for $92.4 \%$ of all serotypes in those children. In the children with BPP, the most common serotypes were $14,6 \mathrm{~B}, 5,1,6 \mathrm{~A}, 9 \mathrm{~V}$, and $19 \mathrm{~F}$, accounting for $84.9 \%$ of all serotypes in those children. In other words, serotypes 1 , $5,6 \mathrm{~B}$, and 14 were found in both PE and BPP, whereas serotypes 6A, 9V, 19A, and 19F were found in either PE or BPP. It is of note that serotypes $6 \mathrm{~A}$ and $19 \mathrm{~A}$ are not included in the 10 -valent pneumococcal conjugate vaccine currently used in Brazil.

To the best of our knowledge, the present study is the first to have focused specifically on BPP and PE in children under 5 years of age. Therefore, the results presented herein cannot be compared with those of other studies. In fact, our analyses showed that demographic characteristics, clinical features, and hematologic findings (i.e., leukocyte counts) are likely to be quite different between children with BPP and those with PE.

Although our objectives and methods were different from those of François et al., ${ }^{(4)}$ some of the results were similar between the two studies. François et al. studied 767 children with CAP and found that $83(11 \%)$ had empyema. ${ }^{(4)}$ The children with CAP and empyema were older and had a longer symptomatic period in comparison with those with CAP without empyema. ${ }^{(4)}$ Interestingly, the length of hospital stay found in the present study was quite similar to that reported in a study involving 33 Brazilian children with empyema (i.e., 12 days). ${ }^{(6)}$ In addition, serotype 1 was one of four serotypes found in both PE and BPP (i.e., $14,1,6 \mathrm{~B}$, and 5), a finding that is consistent with those of the study by François et al., ${ }^{(4)}$ which was conducted in a developed country.

In conclusion, our study investigated CAP patients under 5 years of age and showed clinical and laboratory findings at admission and during the first three days of hospitalization. Our findings can help clinicians and pediatricians to distinguish children with PE from those with BPP. Because these two critical conditions are associated with high rates of morbidity and mortality, prompt clinical, laboratory, and radiological diagnosis is crucial for appropriate management.

\section{References}

1. Grijalva CG, Nuorti JP, Zhu Y, Griffin MR Increasing incidence of empyema complicating childhood communityacquired pneumonia in the United States. Clin Infect Dis. 2010;50(6):805-13. http://dx.doi.org/10.1086/650573 PMid:20166818

2. Roxburgh CS, Youngson GG, Townend JA, Turner SW. Trends in pneumonia and empyema in Scottish children 
in the past 25 years. Arch Dis Child. 2008;93(4):316-8. http://dx.doi.org/10.1136/adc.2007.126540 PMid:18006562

3. Calado C, Nunes P, Pereira L, Nunes T, Barreto C, Bandeira $\mathrm{T}$. Are there any differences in the community acquired pneumonias admitted to hospital over the past decade? Rev Port Pneumol. 2010;16(2):287-305. PMid:20437005

4. François P, Desrumaux A, Cans C, Pin 1, Pavese P, Labarère $\mathrm{J}$ Prevalence and risk factors of suppurative complications in children with pneumonia. Acta Paediatr. 2010;99(6):861-6. http://dx.doi.org/10.1111/j.16512227.2010.01734.x PMid:20178517
5. Cardoso MR, Nascimento-Carvalho CM, Ferrero F, Berezin EN, Ruvinsky R, Camargos PA, et al. Penicillinresistant pneumococcus and risk of treatment failure in pneumonia. Arch Dis Child. 2008;93(3):221-5. http:// dx.doi.org/10.1136/adc.2006.111625 PMid:17848490

6. Amorim PG, Morcillo AM, Tresoldi AT, Fraga Ade M, Pereira RM, Baracat EC. Factors associated with complications of community-acquired pneumonia in preschool children. J Bras Pneumol. 2012;38(5):614-21. http://dx.doi.org/10.1590/S1806-37132012000500011 PMid:23147054

\section{About the authors}

\section{Maria Regina Alves Cardoso}

Associate Professor. Department of Epidemiology, University of São Paulo School of Public Health, São Paulo, Brazil.

\section{Cristiana Maria Costa Nascimento-Carvalho}

Associate Professor 11. Federal University of São Paulo Paulista School of Medicine, São Paulo, Brazil.

\section{Fernando Ferrero}

Researcher. Pedro de Elizalde Children's Hospital, Buenos Aires, Argentina.

\section{Eitan Naaman Berezin}

Associate Professor. Department of Pediatrics, Santa Casa School of Medical Sciences in São Paulo, São Paulo, Brazil.

\section{Raul Ruvinsky}

Head. Department of Maternal and Child Health, Durand Municipal Hospital, Buenos Aires, Argentina.

Clemax Couto Sant'Anna

Associate Professor. Department of Pediatrics, Federal University of Rio de Janeiro School of Medicine, Rio de Janeiro, Brazil.

\section{Maria Cristina de Cunto Brandileone \\ Center Director. Adolfo Lutz Institute, São Paulo, Brazil.}

\section{Maria de Fátima Bazhuni Pombo March}

Associate Professor. Fluminense Federal University, Niterói, Brazil.

\section{Ruben Maggi}

Coordinator. Pediatric Clinic, Professor Fernando Figueira Institute of Integrative Medicine, Recife, Brazil.

\section{Jesus Feris-Iglesias}

Head. Department of Infectious Diseases, Dr. Robert Reid Cabral Children's Hospital, Santo Domingo, Dominican Republic.

\section{Yehuda Benguigui}

Senior Neonatal and Child Health Advisor. Pan American Health Organization, World Health Organization, Washington, DC, USA.

\section{Paulo Augusto Moreira Camargos}

Full Professor of Pediatrics. Federal University of Minas Gerais, Belo Horizonte, Brazil.

\section{the CARIBE group}

The CARIBE group (in alphabetical order): Argentina: Carlos Fernandez Pascua, Carmen Martiarena, Julio Pace, Mabel Regueira, Maria José Rial, Maria Rosa Agosti, Norma Gonzalez, Fernando Torres, Paulina Tagliaferri, Raquel Cosiglio, Sandra Grenon, Silvia Gonzalez Ayala; Brazil: Antônio Cardoso, Claudia Marques, Eduardo Just, Fernando Oliveira, Geraldo Leocádio Filho, Karla Danielle Bomfim, Leda Freitas-Souza, Marcelo Otsuka, Marinalva da Costa Coelho, Mônica Tessinari Tura, Silvana Tadeu Casagrande; Dominican Republic: Hilma Coradín, Jacqueline Sánchez. 